OPEN ACCESS

Edited by:

Hossein Ghezel-Ayagh,

FuelCell Energy, United States

Reviewed by:

Chao-Yi Yuh,

FuelCell Energy, United States

Michel Cassir,

ParisTech École Nationale Supérieure

de Chimie de Paris, France

*Correspondence:

Kevin Huang

huang46@cec.sc.edu

Specialty section:

This article was submitted to

Hydrogen Storage and Production,

a section of the journal

Frontiers in Energy Research

Received: 14 January 2021

Accepted: 19 March 2021

Published: 09 April 2021

Citation:

Zhang P, Wu T and Huang $K$ (2021) Identification of Active Surface Species in Molten Carbonates Using

in situ Raman Spectroscopy.

Front. Energy Res. 9:653527.

doi: 10.3389/fenrg.2021.653527

\section{Identification of Active Surface Species in Molten Carbonates Using in situ Raman Spectroscopy}

\author{
Peng Zhang, Tao Wu and Kevin Huang* \\ Department of Mechanical Engineering, University of South Carolina, Columbia, SC, United States
}

Here we report the results of a study on active surface species of a pristine and modified $(\mathrm{Li}-\mathrm{Na})_{2} \mathrm{CO}_{3}$ eutectic using in situ Raman spectroscopy technique. The effects of gas compositions, temperature, time, and alkaline earth have been systematically studied. The species of $\mathrm{CO}_{4}{ }^{2-}, \mathrm{HCO}_{4}{ }^{-}$, and $\mathrm{C}_{2} \mathrm{O}_{5}{ }^{2-}$ are identified as the three major active species on the surface of $(\mathrm{Li}-\mathrm{Na})_{2} \mathrm{CO}_{3}$ eutectic by a combined Raman spectroscopy and theoretical density functional theory calculations. The results further reveal that $\mathrm{CO}_{4}{ }^{2-}$, $\mathrm{HCO}_{4}{ }^{-}$, and $\mathrm{C}_{2} \mathrm{O}_{5}{ }^{2-}$ are preferably formed in the presence of $\mathrm{O}_{2}, \mathrm{H}_{2} \mathrm{O}$, and high $\mathrm{CO}_{2}$ concentration. With the addition of $\mathrm{Ba}$ to the pristine $(\mathrm{Li}-\mathrm{Na})_{2} \mathrm{CO}_{3}$ eutectic, the Raman $\mathrm{CO}_{4}{ }^{2-} / \mathrm{HCO}_{4}{ }^{-}$shifts become more pronounced.

Keywords: molten carbonate, surface species, Raman spectroscopy, DFT, alkaline earth

\section{INTRODUCTION}

Molten carbonate fuel cells (MCFCs) are a class of energy-efficient and low-emission power generators (Morita et al., 2002; Watanabe et al., 2006; Kawase, 2017). One of their unique features is the use of $\mathrm{CO}_{2}$ and $\mathrm{O}_{2}$ as the cathode gas. The mixture of $\mathrm{CO}_{2}$ and $\mathrm{O}_{2}$ is also a major component in flue gas produced by either coal-fired or natural-gas (NG)-fired power plants. A natural and logical question is if the flue gas can be directly utilized as the oxidant by MCFCs to produce additional power while mitigating the $\mathrm{CO}_{2}$ emission.

The concentration of $\mathrm{CO}_{2}$ emitted by coal-fired power plants is more than twice that emitted by NG-fired power plants, e.g., 10 vs. $4 \%$. The current benchmark MCFCs can operate normally with a $\mathrm{CO}_{2}$ concentration higher than $10 \%$; at lower $\mathrm{CO}_{2}$ concentrations, their performance is significantly limited by diffusion-related concentration polarization. To generate power from MCFCs using low $\mathrm{CO}_{2}$ concentration flue gas produced from NG-fired power plants, the existing MCFC cell/stack technology needs to be further improved to minimize the concentration polarization and meet the performance requirements. In addition, there is a significant amount of $\mathrm{H}_{2} \mathrm{O}$, e.g., $10 \%$, in NG flue gas. The effect of $\mathrm{H}_{2} \mathrm{O}$ on the MCFC performance is not well understood from early studies.

A recent result has confirmed that MCFCs exhibit a high concentration-polarization at low $\mathrm{CO}_{2}$ concentrations and surprisingly enhanced performance in the presence of $\mathrm{H}_{2} \mathrm{O}$ (Rosen et al., 2020). An electrochemical model based on active species peroxide-ion $\left(\mathrm{O}_{2}{ }^{2-}\right)$ and superoxide $\left(\mathrm{O}_{2}{ }^{-}\right)$has been proposed with satisfactory agreement with the experimental data (Cassir et al., 1993). Indeed, an independent Raman spectroscopy study has confirmed the existence of $\mathrm{O}_{2}{ }^{2-}$ on the surface of a $\mathrm{Li}_{2} / \mathrm{K}_{2} \mathrm{CO}_{3}$ eutectic (Chen et al., 2004). 
A parallel conduction mechanism is also proposed for $\mathrm{OH}^{-}$ as a working ion when $\mathrm{H}_{2} \mathrm{O}$ is present in the oxidant feed. From the water mass collected at both cathode and anode sides, it appears to suggest that the conduction mechanism of $\mathrm{OH}^{-}$ in a MC matrix is real (Rosen et al., 2020). However, more experimental evidence related to active species to support water transport is needed.

Raman spectroscopy is a very sensitive technique to detect vibrational modes of $\mathrm{C}-\mathrm{O}-\mathrm{C}, \mathrm{C}-\mathrm{O}$, and $\mathrm{C}=\mathrm{O}$ bonds that are abundant in $\mathrm{C}$-containing species such as $\mathrm{CO}_{3}{ }^{2-}$ and $\mathrm{CO}_{4}{ }^{2-}$ and are of interest to this research (Itoh et al., 2004; Mendoza et al., 2004). We have previously used Raman spectroscopy to probe the surface chemistry of an Ag-MC (Molten Carbonate) membrane operated under a flue gas condition containing $\mathrm{O}_{2}$ and $\mathrm{CO}_{2}$ to facilitate our understanding of why enhanced oxygen permeation was observed (Tong et al., 2016). We concluded from both experimental and theoretical data that $\mathrm{LiCO}_{4}{ }^{-}$was the active species on the Ag-MC membrane surface under simulated flue gas conditions and the extra oxygen in $\mathrm{CO}_{4}{ }^{2-}$ ligand relative to $\mathrm{CO}_{3}{ }^{2-}$ is the reason for the increased oxygen transport. The in situ Raman spectra of the Ag-MC membrane were collected by a LabRam/HR confocal Raman system (LabRam Invers, Horiba Jobin-Yvon) equipped with a $632.8 \mathrm{~nm} \mathrm{He}-\mathrm{Ne}$ laser and hot stage (Linkam TS1500, 0-1,500 ${ }^{\circ} \mathrm{C}$ ). From this work, we were able to identify that $\mathrm{CO}_{4}{ }^{2-}$ is an active species on the surface of an atomic layer deposition $\mathrm{Al}_{2} \mathrm{O}_{3}$-coated Ag$\mathrm{MC}$ composite membrane and explain the phenomenon of the enhanced oxygen flux based on the percarbonate mechanism. In a similar work (Mendoza et al., 2004), we were also able to identify the active surface species as $\mathrm{C}_{2} \mathrm{O}_{5}{ }^{2-}$ with in situ Raman spectroscopy when a MC melt was exposed to a pure $\mathrm{CO}_{2}$ atmosphere.

These prior works demonstrate the versatility and capability of in situ Raman spectroscopy in probing active species on the surface of MC. Therefore, in this study, the in situ Raman spectroscopy technology was selected to identify the species of molten carbonate exposed to varies atmospheres at MCFC operating temperatures.

\section{EXPERIMENTAL}

\section{Sample Preparation}

The molten carbonate compositions under this study were $\mathrm{Li}_{2} \mathrm{CO}_{3}-\mathrm{Na}_{2} \mathrm{CO}_{3}$ eutectic with a ratio of $52: 48 \mathrm{~mol} \%$ (MC), and $10 \mathrm{~mol} \%-\mathrm{SrCO}_{3}$ added $\mathrm{MC}(\mathrm{Sr}-\mathrm{MC})$ and $10 \mathrm{~mol} \%-\mathrm{BaCO}_{3}$ added $\mathrm{MC}(\mathrm{Ba}-\mathrm{MC})$. The reason for selecting $\mathrm{Li}_{2} \mathrm{CO}_{3}-\mathrm{Na}_{2} \mathrm{CO}_{3}$ eutectic was primarily based on the consideration of its higher ionic conductivity than other alkali carbonates eutectics. To prevent MC overflow at high temperatures, an Ag porous matrix was used to contain all MCs. The Ag porous matrix was prepared in the same way as in our previous study (Zhang et al., 2016). Briefly, Ag powders (99.9\% metal basis, Alfa Aesar) were mixed with carbon black as a pore former in a volume ratio of 1:1 in ethanol. The dried power mixture was then pressed into pellets under $70 \mathrm{MPa}$, followed by sintering at $650^{\circ} \mathrm{C}$ for $2 \mathrm{~h}$ in air to remove the carbon pore former and achieve good mechanical strength. Then the porous $\mathrm{Ag}$ pellet was soaked into a $\mathrm{MC}$ at $650^{\circ} \mathrm{C}$ for $2 \mathrm{~h}$ in air, forming Ag/MC composite.

\section{Characterization}

The Raman system used for this study is a Horiba JobinYvon LabRAM HR800. It features a focal length of $800 \mathrm{~mm}$, spectral length of $100-4,000 \mathrm{~cm}^{-1}$ with a spectral resolution up to $1.5 \mathrm{~cm}^{-1}$, accuracy of wavenumber of $1 \mathrm{~cm}^{-1}$ and spatial resolution up to $1 \mu \mathrm{m}$. We use the following operating parameters for Raman spectroscopy study on the surface of a MC:

- Wavelength: $300-1,800 \mathrm{~cm}^{-1}$

- Light source: $632 \mathrm{~nm}$ red

- Acquisition time: $20 \mathrm{~s}$

- Accumulation: 1

- Hole: 500

- Filter: $100 \%$.

The system is also adaptable to high-temperature subsystem for in situ measurements. The high temperature unit (or herein called hot stage) is model Linkam TS1500. The hotstage is connected to a water-cooling system driven by a water circulation pump. The actual temperature was calibrated with the melting point of prepared $\mathrm{MC}\left(490^{\circ} \mathrm{C}\right)$, and temperature effect was studied at 575 and $625^{\circ} \mathrm{C}$. Since the atmosphere effect is a focus of the study, we systematically varied the gas compositions over the MC at a temperature. Table 1 lists all the gas mixtures studied. The total gas flow was fixed at $50 \mathrm{sccm}$ for all measurements.

\section{DFT Calculations}

The equilibrium geometries of species were fully optimized at the B3LYP/6-311G* level using the Gaussian 09 program package (Hehre, 2002; Frisch et al., 2009). To better understand the vibrational modes and figure out fingerprints of these species, Raman spectra were simulated using the B3LYP/6$311 \mathrm{G}^{*}$ basis sets under the harmonic approximation at the same level of geometry optimization. Vibrational analysis showed that all the structures were at minima in the potential energy surface (no imaginary frequencies). Based on the Raman activity obtained from density functional theory (DFT) calculations, the Raman intensity was determined by the GaussSum software (O’Boyle et al., 2008).

TABLE 1 | Gas compositions tested under this project.

\begin{tabular}{ccccc}
\hline Run & $\mathbf{O}_{\mathbf{2}}(\%)$ & $\mathbf{C O}_{\mathbf{2}}(\%)$ & $\mathbf{H}_{\mathbf{2}} \mathbf{O}(\%)$ & $\mathbf{N}_{\mathbf{2}}(\%)$ \\
\hline$\# 1$ & 0 & 0 & 0 & 100 \\
$\# 2$ & 10 & 2 & 0 & Bal. \\
$\# 3$ & 10 & 10 & 0 & Bal. \\
$\# 4$ & 9 & 2 & 10 & Bal. \\
$\# 5$ & 9 & 9 & 10 & Bal. \\
$\# 6$ & 9 & 45 & 10 & Bal. \\
$\# 7$ & 0 & 90 & 10 & 0
\end{tabular}




\section{RESULTS AND DISCUSSION}

\section{Comparison of Raman Spectra in Dry Gas}

Figure 1 compares the Raman spectra at $575^{\circ} \mathrm{C}$ in pure $\mathrm{N}_{2}$ (gas \#1), 2\% $\mathrm{CO}_{2}$ (gas \#2), and $10 \% \mathrm{CO}_{2}$ (gas \#3) atmospheres. The lower intensity of the Raman spectra in $10 \% \mathrm{CO}_{2}$ is due to the presence of $\mathrm{Ag}$ in the Ag-MC sample used to prevent the overflow of the MC. In the following studies, all Raman spectra were collected with the Ag-MC sample. As shown in the Figure 1, the main band at $1,072 \mathrm{~cm}^{-1}$ is assigned to symmetric stretching $\left(v_{1}\right)$ of $\mathrm{O}-\mathrm{C}-\mathrm{O}$, where the bands at $707,885,1,391$, 1,500 , and $1,762 \mathrm{~cm}^{-1}$ correspond to the in-plane bending $\left(v_{4}\right)$ of C-O, out-of-plane bending $\left(v_{2}\right)$ of $\mathrm{O}-\mathrm{C}-\mathrm{O}$, doubly degenerate asymmetric stretching $\left(v_{3}\right)$ of $\mathrm{O}-\mathrm{C}-\mathrm{O}$, and the overtone of the out-of-plane bending mode $\left(2 v_{2}\right)$ vibrations, respectively (Bates et al., 1972; Chen et al., 2002; Zhang et al., 2013). Clearly, there is no difference in these Raman shifts, implying that dry $\mathrm{N}_{2}$ and $\mathrm{CO}_{2}$ conditions do not invoke new species other than $\mathrm{CO}_{3}{ }^{2-}$. Similar phenomenon was also observed in our previous study, where there is no new peak in the dry gas conditions with Ag-MC sample (Tong et al., 2016).

The temperature and time effect on the Raman spectra of the Ag-MC samples in dry $10 \% \mathrm{CO}_{2}$ atmosphere (gas \#3) are compared in Figure 2. Figures 2A,B show the Raman spectra of the Ag-MC sample at 575 and $625^{\circ} \mathrm{C}$, respectively. These results confirm that there is no difference in spectrum in dry gas at both temperatures.

\section{$\mathrm{CO}_{2}$ Concentration Effect in Wet Gas}

To investigate why steam promotes the MCFC performance, we also conducted the Raman spectroscopy of the Ag-MC sample in wet gas $\left(10 \% \mathrm{H}_{2} \mathrm{O}\right)$ with different $\mathrm{CO}_{2}$ concentrations. For an easy comparison, the Raman spectra in dry $\mathrm{N}_{2}$ is also shown in Figure 3. Some new shift between 400 and $607 \mathrm{~cm}^{-1}$ appear in wet $\mathrm{CO}_{2}$ atmospheres. To identify these new shifts, DFT calculations were performed. From the DFT calculations, the weak but new shifts at 409 and $567 \mathrm{~cm}^{-1}$ seem to relate to $\mathrm{HCO}_{4}{ }^{-}$, while the weak but new shifts at $607 \mathrm{~cm}^{-1}$ can be assigned to $\mathrm{CO}_{4}{ }^{2-}$. These two species are observed in $\mathrm{CO}_{2}$ concentration gases from 2 to $45 \% \mathrm{CO}_{2}$, while at high $\mathrm{CO}_{2}$-concentraiton, e.g., $90 \% \mathrm{CO}_{2}, \mathrm{C}_{2} \mathrm{O}_{5}{ }^{2-}$ species appears at $455 \mathrm{~cm}^{-1}$. The observation of $\mathrm{C}_{2} \mathrm{O}_{5}{ }^{2-}$ species at high $\mathrm{CO}_{2}$ concentration is reasonable given the fact that $\mathrm{CO}_{2}$ dissolution into $\mathrm{MC}$ to form $\mathrm{C}_{2} \mathrm{O}_{5}{ }^{2-}$ by $\mathrm{CO}_{2}+\mathrm{CO}_{3}{ }^{2-}=\mathrm{C}_{2} \mathrm{O}_{5}{ }^{2-}$ (Claes et al., 1996).

When the gas atmosphere changed from dry $\mathrm{N}_{2}$ to wet $2 \%$ $\mathrm{CO}_{2}$, the weak but new bands at 567 and $607 \mathrm{~cm}^{-1}$ seem to emerge, which correspond to $\mathrm{HCO}_{4}{ }^{-}$and $\mathrm{CO}_{4}{ }^{2-}$, respectively. (Note: the wet $2 \% \mathrm{CO}_{2}$ gas also contains $9 \% \mathrm{O}_{2}$, see Table $\mathbf{1}$, gas \#4). Then the intensity of the new bands slightly increased by increasing $\mathrm{CO}_{2}$ concentration to 9 and $45 \%$. The formation mechanisms for the observed $\mathrm{HCO}_{4}{ }^{-}$and $\mathrm{CO}_{4}{ }^{2-}$ are (Zhang et al., 2014; Tong et al., 2016):

$$
\begin{gathered}
\mathrm{H}_{2} \mathrm{O}+2 \mathrm{CO}_{2}+3 / 2 \mathrm{O}_{2}+2 \mathrm{e}^{-}=2 \mathrm{HCO}_{4}^{-} \\
\mathrm{CO}_{2}+3 / 2 \mathrm{O}_{2}+\mathrm{CO}_{3}^{2-}+2 \mathrm{e}^{-}=2 \mathrm{CO}_{4}^{2-}
\end{gathered}
$$

From these reactions, $\mathrm{H}_{2} \mathrm{O}$ is essential to form $\mathrm{HCO}_{4}{ }^{-}$, but not for $\mathrm{CO}_{4}{ }^{2-}$ species. However, it is interesting to see that $\mathrm{CO}_{4}{ }^{2-}$ appears in wet flue gas but not in dry flue gas (i.e., $\sim 10 \% \mathrm{CO}_{2}$ $10 \% \mathrm{O}_{2}$ ), see Figure $2 \mathrm{~B}$. A possible reason is that the steam facilitates the dissolution of $\mathrm{O}_{2}$ into $\mathrm{MC}$. From Figure 3, $\mathrm{HCO}_{4}{ }^{-}$ and $\mathrm{CO}_{4}{ }^{2-}$ bands disappear and $\mathrm{C}_{2} \mathrm{O}_{5}{ }^{2-}$ band appear with

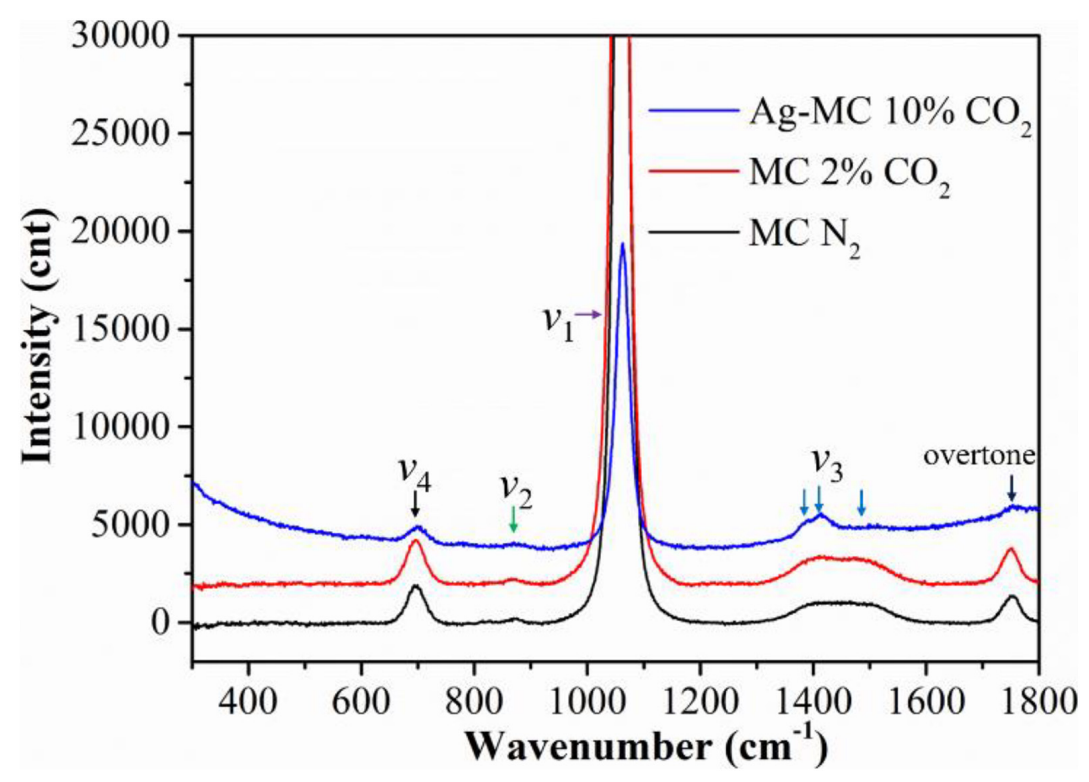

FIGURE 1 | The Raman spectra of the MC/Ag-MC samples at $575^{\circ} \mathrm{C}$ in dry gas atmospheres with different $\mathrm{CO}_{2}$ concentration. $\left(\mathrm{N}_{2}:\right.$ gas \#1, $2 \% \mathrm{CO}_{2}:$ gas \#2, $10 \%$ $\mathrm{CO}_{2}$ : gas \#3). 

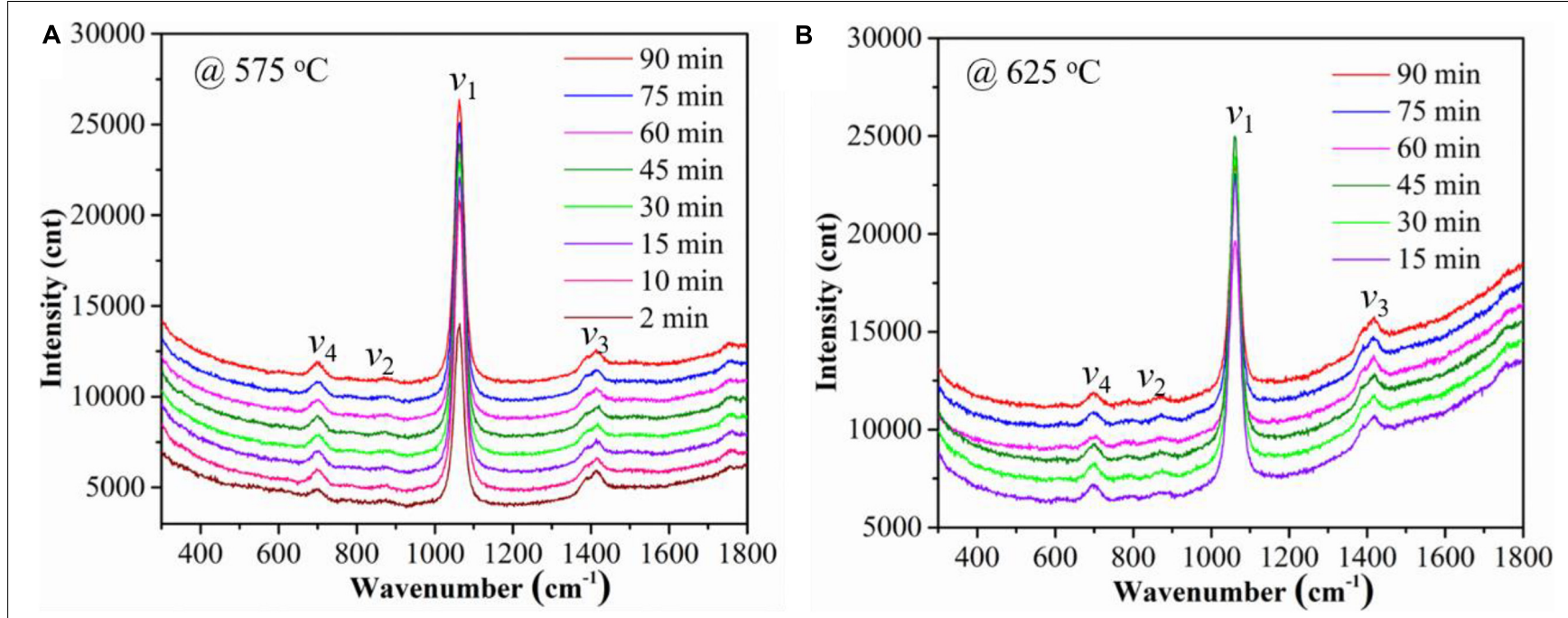

FIGURE 2 | The effects of temperature and time on Raman spectra of the Ag-MC sample in dry $10 \% \mathrm{CO}_{2}$ gas (gas \#3). (A) $575^{\circ} \mathrm{C}$ and (B) $625^{\circ} \mathrm{C}$.

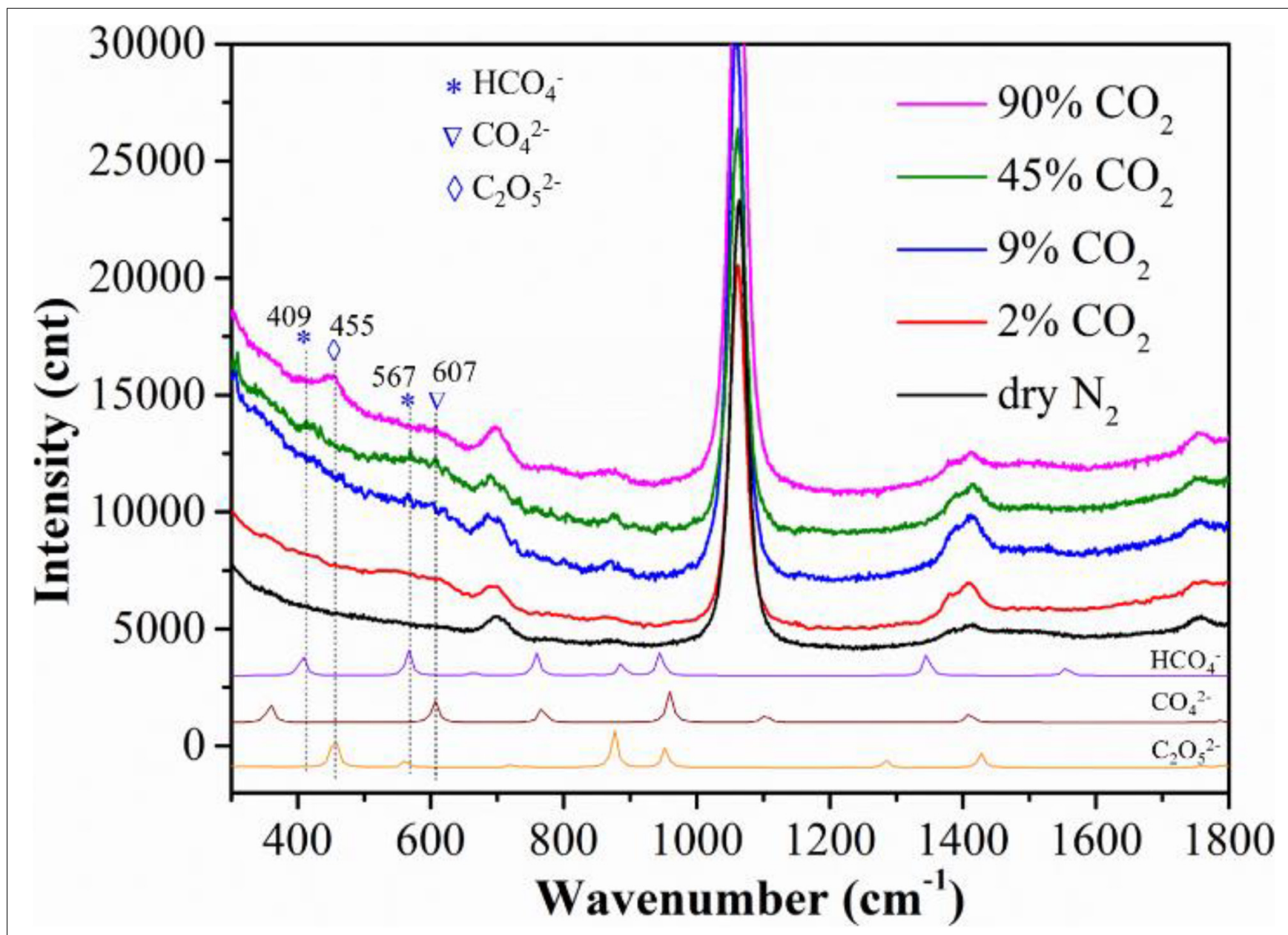

FIGURE 3 | Raman spectra, along with DFT calculations, of the Ag-MC sample collected at $625^{\circ} \mathrm{C}$ in different $\mathrm{CO}_{2}$ concentration gas conditions: dry $\mathrm{N}_{2}$ (gas \#1), $2 \% \mathrm{CO}_{2}$ (gas \#4), $9 \% \mathrm{CO}_{2}$ (gas \#5), $45 \% \mathrm{CO}_{2}$ (gas \#6), $90 \% \mathrm{CO}_{2}$ (gas \#7). 
further increasing $\mathrm{CO}_{2}$ concentration to $90 \%$ (no $\mathrm{O}_{2}$ ), which is consistent with our previous study (Zhang et al., 2013).

\section{The Effect of Alkaline Earth-Addition to MC}

To further confirm that the formation of $\mathrm{HCO}_{4}{ }^{-}$and $\mathrm{CO}_{4}{ }^{2-}$ is highly influenced by the solubility of molecular oxygen, and therefore, the basicity in MCs. We measured the Raman spectra of alkaline earth-addition MC, since it has been reported that the alkaline earth metals can enhance the oxygen solubility of the molten carbonate (Scaccia and Frangini, 2009). At first, the Raman spectra of $\mathrm{Ba}$ - and Sr-added $\mathrm{MC}$ under in $45 \% \mathrm{CO}_{2}$ $10 \% \mathrm{O}_{2}-10 \% \mathrm{H}_{2} \mathrm{O}-\mathrm{N}_{2}$ atmosphere (gas \#6) were collected and are shown in Figure 4. It seems that Sr-doped MC sample show similar new bands with the pristine MC sample. However, the intensities of $\mathrm{HCO}_{4}{ }^{-}$and $\mathrm{CO}_{4}{ }^{2-}$ bands of Ba-added $\mathrm{MC}$ samples are increased appreciably. In addition, a couple of more pronounced new peaks at $\sim 360$ and $770 \mathrm{~cm}^{-1}$ are observed of the Ba-added sample. Compared to DFT-calculated Raman bands, it is determined that the new shift is related to $\mathrm{CO}_{4}{ }^{2-}$. These results further suggest that high oxygen solubility promotes the formation of $\mathrm{CO}_{4}^{-}$.

Since both the $\mathrm{H}_{2} \mathrm{O}$ and alkaline earth metals increase the oxygen solubility of MCs, we also conducted Raman study of the $\mathrm{Ba}-\mathrm{MC}$ sample under dry gas condition. Figure 5 shows that the $\mathrm{Ba}-\mathrm{MC}$ sample does exhibit new surface species under $\mathrm{CO}_{2}$-free, $\mathrm{H}_{2} \mathrm{O}$-free and wet gas conditions. Similar Raman spectra were obtained under the dry flue gas and wet $45 \% \mathrm{CO}_{2}$ atmosphere, confirming that the oxygen solubility highly influences the formation of $\mathrm{CO}_{4}{ }^{2-}$ and $\mathrm{HCO}_{4}{ }^{-}$. Figure 5 also shows significant appearance of new shifts at 403 and $803 \mathrm{~cm}^{-1}$ under dry $10 \% \mathrm{O}_{2}$ condition. DFT calculations suggest that it is related to $\mathrm{BaCO}_{3}$.
This finding implies that $\mathrm{Ba}-\mathrm{MC}$ is unstable under dry $10 \% \mathrm{O}_{2}$ $\mathrm{N}_{2}$, precipitating out $\mathrm{BaCO}_{3}$ on the $\mathrm{MC}$ surface. However, in the presence of both $\mathrm{H}_{2} \mathrm{O}$ and $\mathrm{CO}_{2}, \mathrm{BaCO}_{3}$ re-dissolves back into $\mathrm{MC}$, but with a pronounced shift at $\sim 600 \mathrm{~cm}^{-1}$ relating to species $\mathrm{HCO}_{4}{ }^{-}$and $\mathrm{CO}_{4}{ }^{2-}$. In addition, the new shift at $360 \mathrm{~cm}^{-1}$ is attributed to $\mathrm{CO}_{4}{ }^{2-}$ according to the DFT calculation, further indicating that the Ba-added MC enhances oxygen solubility. For convenience, we show in Figure 6 a schematic of the $\mathrm{BaCO}_{3}$ precipitation and re-dissolution mechanisms in dry $\mathrm{O}_{2}$ and $\mathrm{CO}_{2}$ $\mathrm{H}_{2} \mathrm{O}-\mathrm{O}_{2}$-containing gas mixtures, respectively.

Overall, based on the above Raman spectroscopic results, we propose the following mechanisms for $\mathrm{CO}_{2}$ and $\mathrm{H}_{2} \mathrm{O}$ transport in MCFCs with a high-basicity $\mathrm{MC}$ as the electrolyte, $\mathrm{H}_{2}$ as the anode gas and $\mathrm{CO}_{2} / \mathrm{H}_{2} \mathrm{O} / \mathrm{O}_{2}$ as the cathode gas:

At Cathode:

$$
\text { Main reaction : } \mathrm{CO}_{2}+1 / 2 \mathrm{O}_{2}+2 \mathrm{e}^{-}=\mathrm{CO}_{3}^{2-}
$$

Parallel reaction (1) :

$$
\begin{gathered}
\mathrm{H}_{2} \mathrm{O}+2 \mathrm{CO}_{2}+3 / 2 \mathrm{O}_{2}+2 \mathrm{e}^{-}=2 \mathrm{HCO}_{4}^{-} \text {(intermediate) } \\
\mathrm{HCO}_{4}^{-}+2 \mathrm{e}^{-}=\mathrm{OH}^{-}+\mathrm{CO}_{3}^{2-}
\end{gathered}
$$

At Anode:

$$
\begin{aligned}
& \text { Main reaction : } \mathrm{CO}_{3}^{2-}+\mathrm{H}_{2}=\mathrm{H}_{2} \mathrm{O}+\mathrm{CO}_{2}+2 \mathrm{e}^{-} \\
& \text {Parallel reaction (1) : } 2 \mathrm{OH}^{-}+\mathrm{H}_{2}=2 \mathrm{H}_{2} \mathrm{O}+2 \mathrm{e}^{-}
\end{aligned}
$$

Since $\mathrm{HCO}_{4}{ }^{-}$is virtually an intermediary species, the experimentally observed $\mathrm{H}_{2} \mathrm{O}$ and $\mathrm{CO}_{2}$ transport in MCFC are carried out by $\mathrm{OH}^{-}$and $\mathrm{CO}_{3}{ }^{2-}$.

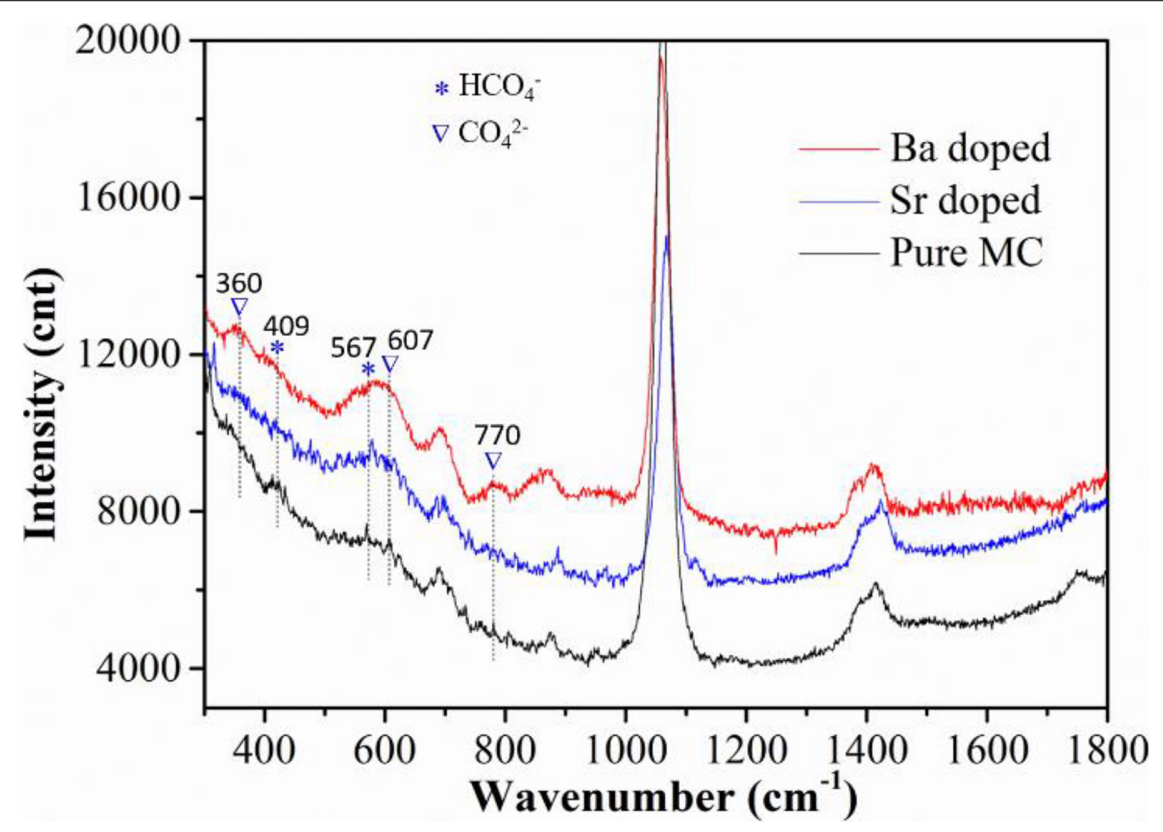

FIGURE 4 | Comparison of Raman spectra of three types of Li-Na MC (Ba-MC, Sr-MC, and MC) exposed to $45 \% \mathrm{CO}_{2}-10 \% \mathrm{O}_{2}-10 \% \mathrm{H}_{2} \mathrm{O}-\mathrm{N}_{2}$ atmosphere at $625^{\circ} \mathrm{C}$. 


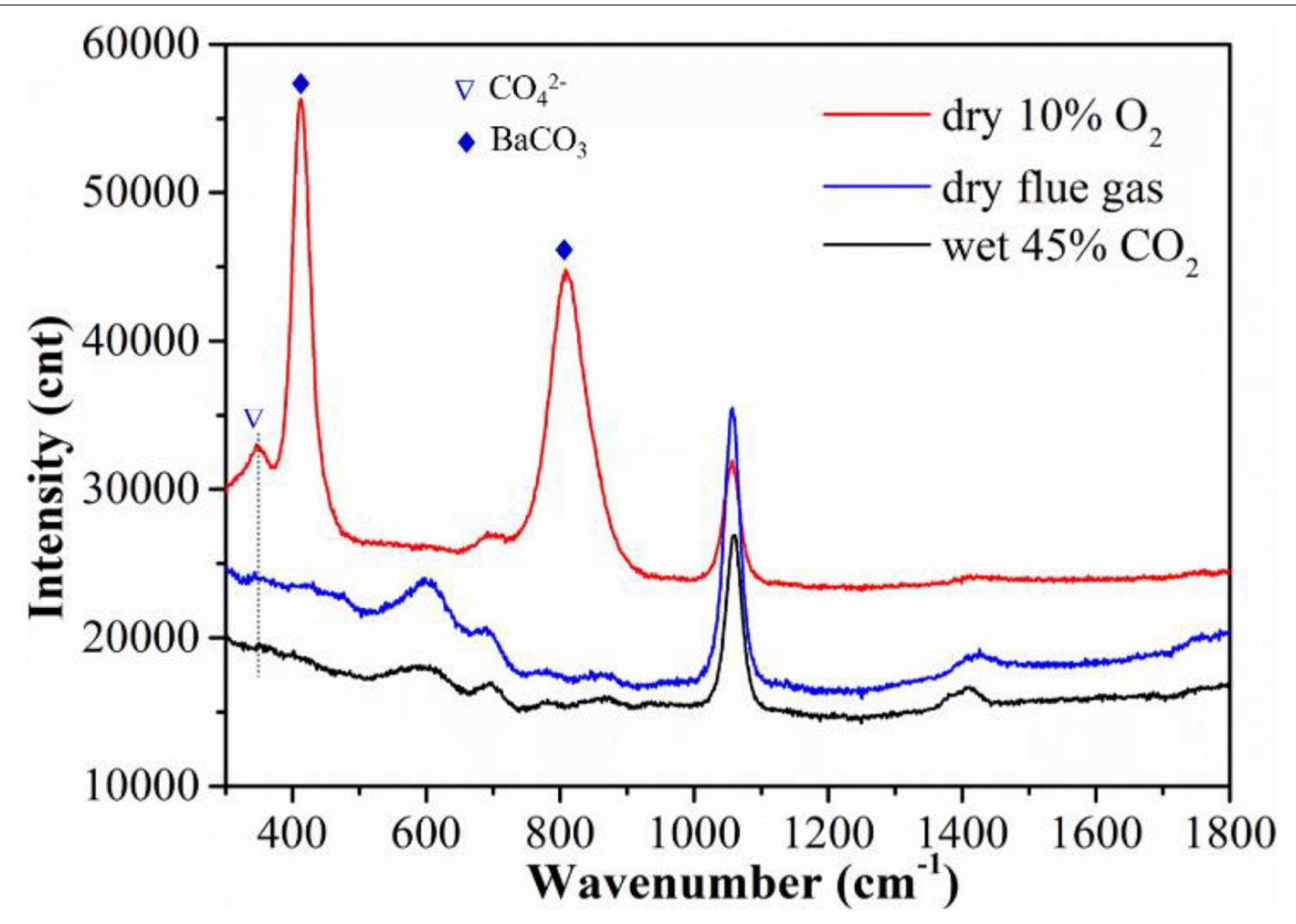

FIGURE 5 | Raman spectra of Ba-added MC collected under different gas conditions at $625^{\circ} \mathrm{C}$.

$\underline{\ln \text { dry } \mathrm{O}_{2}}$

$\mathrm{BaCO}_{3}$ precipitate

$(\mathrm{Li}-\mathrm{Na})_{2} \mathrm{CO}_{3}-\mathrm{BaCO}_{3}$

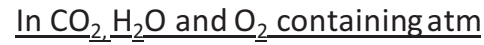

$\mathrm{HCO}_{4}^{-}$and $\mathrm{CO}_{4}^{2-}$

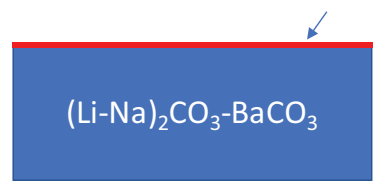

FIGURE 6 | Surface species of Ba-added MC exposed to different gas mixtures.

\section{CONCLUSION}

In summary, the surface chemistry of pristine and $\mathrm{Ba}$ - or Srmodified Li-Na eutectic under seven gas mixtures has been studied by in situ Raman spectroscopy. Compared to the pristine $\mathrm{MC}$ under dry $\mathrm{N}_{2}$, all the $\mathrm{CO}_{2}$-containing dry gas conditions do not change Raman spectra of the MC. Under wet gas conditions, relatively weak new shifts appear in 300$700 \mathrm{~cm}^{-1}$ and their intensities increase with $\mathrm{CO}_{2}$ concentration. Assisted by DFT calculations, the new shifts are identified to be $\mathrm{CO}_{4}{ }^{2-} / \mathrm{HCO}_{4}{ }^{-}$at low $\mathrm{CO}_{2}$ concentrations and $\mathrm{C}_{2} \mathrm{O}_{5}{ }^{2-}$ at high $\mathrm{CO}_{2}$ concentrations. With the addition of $\mathrm{Ba}$ to the pristine $\mathrm{MC}$, the $\mathrm{CO}_{4}{ }^{2-} / \mathrm{HCO}_{4}{ }^{-}$shifts become more pronounced due to enhanced oxygen solubility in MC. It was also discovered that $\mathrm{BaCO}_{3}$ can precipitate out under $\mathrm{CO}_{2}$-free dry gas environment. Based on the found surface intermediate species, a mechanism concerning $\mathrm{H}_{2} \mathrm{O}$ and $\mathrm{CO}_{2}$ co-transport is proposed.

\section{DATA AVAILABILITY STATEMENT}

The original contributions presented in the study are included in the article/supplementary material, further inquiries can be directed to the corresponding author/s.

\section{AUTHOR CONTRIBUTIONS}

PZ conducted the experiment. TW performed the DFT calculations. $\mathrm{KH}$ conceived the idea. All authors contributed to the article and approved the submitted version. 


\section{FUNDING}

Financial supports from National Science Foundation (Award \# 1924095) and ExxonMobil are greatly appreciated.

\section{REFERENCES}

Bates, J. B., Brooker, M. H., Quist, A. S., and Boyd, G. E. (1972). Raman spectra of molten alkali metal carbonates. J. Phys. Chem. 76, 1565-1571. doi: 10.1021/ j100655a013

Cassir, M., Moutiers, G., and Devynck, J. (1993). Stability and characterization of oxygen species in alkali molten carbonate: a thermodynamic and electrochemical approach. J. Electrochem. Soc. 140:3114. doi: 10.1149/1. 2220995

Chen, L., Lin, C., Zuo, J., Song, L., and Huang, C. (2004). First spectroscopic observation of peroxocarbonate/ peroxodicarbonate in molten carbonate. J. Phys. Chem. B 108, 7553-7556. doi: 10.1021/jp0357491

Chen, L.-J., Cheng, X., Lin, C.-J., and Huang, C.-M. (2002). In-situ Raman spectroscopic studies on the oxide species in molten $\mathrm{Li} / \mathrm{K}_{2} \mathrm{CO}_{3}$. Electrochim. Acta 47, 1475-1480. doi: 10.1016/s0013-4686(01)00872-6

Claes, P., Thirion, B., and Glibert, J. (1996). Solubility of $\mathrm{CO}_{2}$ in the molten $\mathrm{Na}_{2} \mathrm{CO}_{3}-\mathrm{K}_{2} \mathrm{CO}_{3}(42 \mathrm{~mol} \%)$ eutectic mixture at $800{ }^{\circ} \mathrm{C}$. Electrochim. Acta 41 , 141-146. doi: 10.1016/0013-4686(95)00278-m

Frisch, M. J. E. A., Trucks, G. W., Schlegel, H. B., Scuseria, G. E., Robb, M. A., Cheeseman, J. R., et al. (2009). Gaussian 09, Revision d. 01.Wallingford CT: Gaussian. Inc, 201.

Hehre, W. J. (2002). Ab initio molecular orbital theory. Acc. Chem. Res. 9, 399-406.

Itoh, T., Abe, K., Dokko, K., Mohamedi, M., Uchida, I., and Kasuya, A. (2004). In situ raman spectroelectrochemistry of oxygen species on gold electrodes in high temperature molten carbonate melts. J. Electrochem. Soc. 151:A2042.

Kawase, M. (2017). Durability and robustness of tubular molten carbonate fuel cells. J. Power Sources 371, 106-111. doi: 10.1016/j.jpowsour.2017.10.024

Mendoza, L., Baddour-Hadjean, R., Cassir, M., and Pereira-Ramos, J. P. (2004). Raman evidence of the formation of $\mathrm{LT}-\mathrm{LiCoO}_{2}$ thin layers on $\mathrm{NiO}$ in molten carbonate at 650 C. Appl. Surf. Sci. 225, 356-361. doi: 10.1016/j.apsusc.2003. 10.026

Morita, H., Komoda, M., Mugikura, Y., Izaki, Y., Watanabe, T., Masuda, Y., et al. (2002). Performance analysis of molten carbonate fuel cell using a $\mathrm{Li} / \mathrm{Na}$ electrolyte. J. Power Sources 112, 509-518. doi: 10.1016/s0378-7753(02)00468-8

O’Boyle, N. M., Tenderholt, A. L., and Langner, K. M. (2008). cclib: a library for package-independent computational chemistry algorithms. J. Comput. Chem. 29, 839-845. doi: $10.1002 /$ jcc. 20823

\section{ACKNOWLEDGMENTS}

The authors would like to acknowledge constructive discussion with Timothy A. Barckholtz, Gabor Kiss, and David Perkins at ExxonMobil.

Rosen, J., Geary, T., Hilmi, A., Blanco-Gutierrez, R., Yuh, C.-Y., Pereira, C. S., et al. (2020). Molten carbonate fuel cell performance for $\mathrm{CO}_{2}$ capture from natural gas combined cycle flue gas. J. Electrochem. Soc. 167:064505. doi: 10.1149/19457111/ab7a9f

Scaccia, S., and Frangini, S. (2009). Effect of Ba and Ca additions on the oxygen solubility properties of a (70/30) mol\% $\mathrm{Li}_{2} \mathrm{CO}_{3} / \mathrm{Na}_{2} \mathrm{CO}_{3}$ carbonate melt. J. Mol. Liq. 146, 39-43. doi: 10.1016/j.molliq.2009.01.011

Tong, J., Lei, X., Fang, J., Han, M., and Huang, K. (2016). Remarkable $\mathrm{O}_{2}$ permeation through a mixed conducting carbon capture membrane functionalized by atomic layer deposition. J. Mater. Chem. A. 4, 1828-1837. doi: 10.1039/c5ta10105k

Watanabe, T., Izaki, Y., Mugikura, Y., Morita, H., Yoshikawa, M., Kawase, M., et al. (2006). Applicability of molten carbonate fuel cells to various fuels. J. Power Sources $160,868-871$.

Zhang, L., Huang, X., Qin, C., Brinkman, K., Gong, Y., Wang, S., et al. (2013). First spectroscopic identification of pyrocarbonate for high $\mathrm{CO}_{2}$ flux membranes containing highly interconnected three dimensional ionic channels. Phys. Chem. Chem. Phys. 15, 13147-13152. doi: 10.1039/c3cp52362d

Zhang, L., Tong, J., Gong, Y., Han, M., Wang, S., and Huang, K. (2014). Fast electrochemical $\mathrm{CO}_{2}$ transport through a dense metal-carbonate membrane: a new mechanistic insight. J. Membr. Sci. 468, 373-379. doi: 10.1016/j.memsci. 2014.06.028

Zhang, P., Tong, J., Jee, Y., and Huang, K. (2016). Stabilizing a high-temperature electrochemical silver-carbonate $\mathrm{CO}_{2}$ capture membrane by atomic layer deposition of a $\mathrm{ZrO}_{2}$ overcoat. Chem. Commun. 52, 9817-9820. doi: 10.1039/ c6cc04501d

Conflict of Interest: The authors declare that the research was conducted in the absence of any commercial or financial relationships that could be construed as a potential conflict of interest.

Copyright (c) 2021 Zhang, Wu and Huang. This is an open-access article distributed under the terms of the Creative Commons Attribution License (CC BY). The use, distribution or reproduction in other forums is permitted, provided the original author(s) and the copyright owner(s) are credited and that the original publication in this journal is cited, in accordance with accepted academic practice. No use, distribution or reproduction is permitted which does not comply with these terms. 